STRUCTURAL BIOLOGY

ISSN 2059-7983

\section{A Life among Men, Women and Molecules. Memoirs of an Indian Scientist. By MaMannaMana Vijayan. Indian National Science Academy, 2020. Ebook, pp. xi+305. ISBN 978-81-939482-6-2. Price USD 35.00 INR $1500^{1}$}

\author{
Edward N. Baker*
}

School of Biological Sciences, University of Auckland, Private Bag 92-019, Auckland, New Zealand. *Correspondence e-mail: en.baker@auckland.ac.nz

The role and importance of mentors is a cultural theme that runs through all fields of science. Some years ago, I had the privilege of reviewing a set of three volumes containing the collected works of Dorothy Hodgkin, one of our greatest and most influential crystallographers. Those volumes were published through the Indian Academy of Sciences. A generation later, it is an honour to also review the autobiographical memoirs of Professor Mamannamana Vijayan (known to all simply as Vijayan). As a young and idealistic PhD student determined to make a career in crystallography, Vijayan met Dorothy in India and was delighted to be able to later join her research group in Oxford. There he embraced the excitement of this pivotal time in the development of macromolecular crystallography, and the warmth and sense of family that characterized Dorothy's insulin group. And it is these qualities that shine through this book.

Now retired, Vijayan has written a fascinating account of his life in science, during which he has played a crucial role in the development of macromolecular crystallography in India, while simultaneously making extraordinarily broad contributions to Indian science in general. This is a book that illuminates not only a fascinating era of crystallographic history but also the rich cultural and scientific diversity of India, seen from the standpoint of an outstanding and internationally engaged Indian scientist.

The book begins, appropriately, in Kerala where Vijayan was born into a politically engaged family at a time of optimism for change in a country newly emerging from colonial rule. His roots in Kerala have remained a touchstone throughout his life, bringing a strong commitment to equality and fairness, and a desire that national development should benefit all. These themes reappear throughout subsequent chapters, and have informed all the national roles he has taken.

He describes his entry into crystallography, as a physics student at Allahabad University, as the sort of revelation that many readers of this book will have experienced themselves - myself included. There follow a series of chapters that form the crystallographic heart of this memoir. His PhD studies in a nascent crystallography group at the Indian Institute of Science - as the oldest student, he was in charge of the laboratory enabled him to meet many visiting scientists. Crucially, a meeting with Dorothy Hodgkin in 1967 led him to work with her in Oxford a year later. There follows a fascinating account of his transformative experience over the next three years: the bleak cold of arrival in an English winter, contrasted with the warmth of relationships with Dorothy and the close-knit insulin group that included Guy and Eleanor Dodson, Tom Blundell and myself; new cultural experiences; the excitement of the insulin structure solution; presentations at international conferences and meetings with long-admired figures such as Max Perutz; and Dorothy's personal intervention to enable his fiancée Kalyani to travel to Oxford to marry him there. The social ferment of the late 1960s also directed his progressive instincts towards a lifelong commitment to India. A postscript to this time in Oxford came five years later, when a need for specialist medical intervention to enable the safe birth of Vijayan and Kalyani's daughter Devi led Dorothy to bring them both back to Oxford for a further year's visit. Very much the human touch to science.

Chapters 6 and 7 describe Vijayan's efforts to establish macromolecular crystallography in Bangalore. As was common in the 1970s, there were many who doubted 
whether it was possible outside the major centres of Europe and North America (this was also my experience in New Zealand). The arrival of G. N. Ramachandran (GNR) to set up the Molecular Biophysics Unit (MBU) in 1971 helped greatly, and Vijayan pays a heartfelt tribute to him. He also describes the honour he felt when asked by the IUCr to accept the Ewald Prize on GNR's behalf and give a valedictory lecture at the Glasgow IUCr Congress.

Vijayan moved from Physics to the MBU in 1974, but the MBU faced other problems; political problems with the USA that made it difficult to obtain modern equipment; GNR's departure in 1978; the need to boost biological input; and to overcome power disruptions and air conditioning needs. Major equipment funding was finally won in 1983, and Vijayan assumed the leadership of MBU in 1984. It is quite inspiring to read here how, under his leadership, a 'small group of relative greenhorns' managed to develop a group that has populated Indian institutions with many highly decorated scientists Vijayan's 'students and grand-students'. It is clear that much thought was put into appointments to ensure balance and coherence, and I have myself seen at first hand the extraordinary affection in which Vijayan is now held by all.

Chapters 8-10 describe the realization of Vijayan's dream to establish a macromolecular crystallography program in India. In order to overcome the initial equipment deficits, he describes some innovative projects that could be pursued in the meantime: structural studies of non-steroidal anti-inflammatory drugs; ionophores and related molecules; crystalline complexes involving amino acids and peptides that were aimed at exploring the origins of life. Integration with biology was more difficult. Vijayan makes the point that modern biology was essentially a post-independence subject in India, and much less developed than chemistry and physics. He thus describes his efforts to immerse himself fully into the youthful Indian biology community, to develop the linkages that could bring biology and crystallography together. He describes his own work on lectins, which established a strong international profile, and then a program on mycobacterial proteins that helped to fully establish recombinant DNA technologies. This has become a flagship area for India, and is one that he returns to at the end of the book as unfinished business. Vijayan expresses one major regret, in the failure to establish a stateof-the-art national synchrotron facility. He describes strenuous efforts to do so over 30 years, ultimately stymied by regional rivalries and changes of governments, wryly noting this as a goal that remains to be realized in the future.
Reading this book brought home to me the complexities of science organization in a country as large as India, with so many universities and other institutions of higher education and research, and such a large student cohort thirsting after education. Vijayan describes three different national science academies, on each of which he was an elected Fellow. In an extraordinary record of service, he served on the councils of all three at different times, and was President of the major one, the Indian National Science Academy (INSA) in 2007-2010. In this role he also attended the annual meetings of $\mathrm{G} 8+5$ Academy Presidents, accompanying the ministerial meetings of G8+5 countries. He describes an even larger record of national and international engagement in both biophysics and crystallography, organizing national meetings in both disciplines, serving on their councils, mediating in disputes of various kinds, and playing major roles in both International Unions, IUCr and IUPAB. Any reader of this book who feels bogged down by administrative duties can only read this and marvel. Vijayan's contributions have been massive.

The book finishes with three very personal chapters that complete a very rounded memoir. Here, Vijayan pays tribute to the strengths of family relationships that have sustained him through his life and must have made his extensive travel to scientific and administrative commitments more tolerable. As he describes it, India seems like a large extended family! He revisits his beloved Kerala as a touchstone for thoughts about national development. Noting Kerala's success in virtually eliminating food shortages and achieving almost $100 \%$ literacy, he also sees the downsides that come with prosperity: rampant consumerism, loss of simplicity, rising populism and fundamentalism, and a more fractured society. Similar thoughts are expressed in earlier chapters, where, representing India at G8+5 meetings, he strongly advocated that sustainable development must be accompanied by sustainable consumption - the concerns of one who cares deeply about his whole society. Finally, in a very moving chapter, he describes his own ongoing struggle with motor neuron disease, paying tribute to Kalyani, his wife, for her loving care.

This is a book that all crystallographers will enjoy for its depiction of a remarkable period in the history of our field. But it is much more than that. For those who do not know India it is a window into a rich, vibrant and fascinating society, and for Indians and those who know the country well it is a unique insight into the life and thoughts of one of India's most loved and influential scientists. Vijayan's many friends around the world will treasure this book. 